\title{
Potential treatments in the management of covid-19
}

Potenciais tratamentos no manejo do covid-19

Tratamientos potenciales en la gestion de covid-19

Luiza Miranda Marinho de Paula ${ }^{1 *}$, Jhonson Tizzo Godoy², Arthur Alves Baldo ${ }^{3}$, Henrique Chagas Costa $^{1}$, Isabela Soares Bôa Morte ${ }^{4}$, Lara Andrade Braga ${ }^{5}$, Larissa Caires Gonzaga ${ }^{6}$, Marcella Resende Monteiro do Prado ${ }^{5}$, Adriel Gustavo Lopes ${ }^{1}$.

\begin{abstract}
Objective: To provide a tool to assist health professionals in the medical clinic regarding treatments still under study to combat COVID-19 and serve as a basis for future studies. Methods: For the development of this systematic review, research was carried out on the Embase, Pubmed databases and on the website clinicaltrials.gov, with the following inclusion criteria: selection of clinical trials carried out in adults, randomized or not, who addressed the discussion on the treatment or development of vaccines for COVID-19. Of the articles found, 22 studies were selected and those with a different methodological design were excluded. Results: The studies cover clinical trials that are divided into double or triple blind and present a low risk of bias. Among the tested interventions, Hydroxychloroquine and antivirals are the drugs that show the most promise in controlling the disease. The final results, however, are not yet available, as studies are ongoing. Final considerations: There is still no scientific evidence to recommend the use of any of the tested drugs, making it necessary to continue and maintain ongoing studies.
\end{abstract}

Keywords: Covid-19, Therapy, Pandemics.

\section{RESUMO}

Objetivo: Fornecer uma ferramenta que auxilie os profissionais de saúde na clínica médica com relação aos tratamentos ainda em estudo para combate ao COVID-19 e servir como base para estudos futuros. Métodos: Para o desenvolvimento desta revisão sistemática, foram realizadas pesquisas nas bases de dados Embase, Pubmed e no site clinicaltrials.gov, com os seguintes critérios de inclusão: seleção de ensaios clínicos realizados em adultos, randomizados ou não, que abordaram a discussão sobre o tratamento ou desenvolvimento de vacinas para o COVID-19. Dos artigos encontrados, foram selecionados 22 estudos e excluídos aqueles que apresentavam desenho metodológico diferente do desejado. Resultados: Os estudos abrangem ensaios clínicos que se dividem em duplo ou triplo cego e apresentam baixo risco de viés. Dentre as intervenções testadas, a Hidroxicloroquina e os antivirais são os medicamentos que se mostram mais promissores no controle da doença. Os resultados finais, no entanto, ainda não estão disponíveis, visto que os estudos estão em andamento. Considerações finais: Ainda não há comprovação científica que recomende $\mathrm{o}$ uso de nenhum dos medicamentos testados, se fazendo necessária a continuidade e manutenção dos estudos em andamento.

Palavras-chave: Covid-19, Terapia, Pandemias.

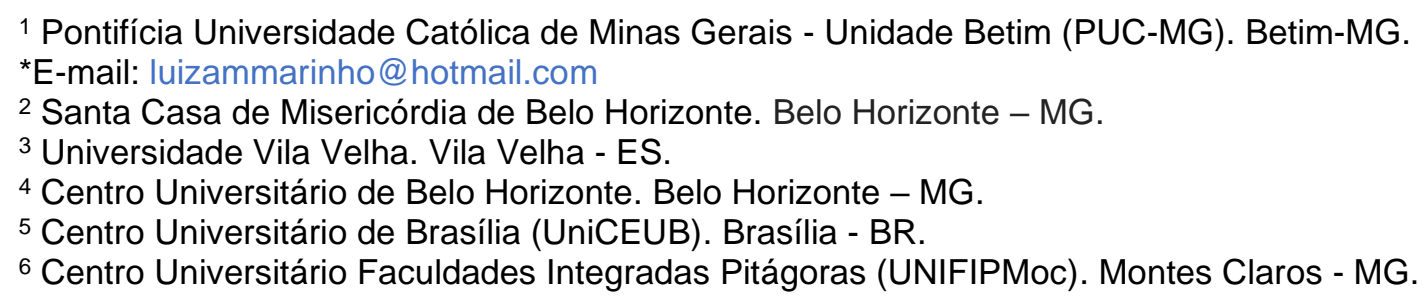




\section{RESUMEN}

Objetivo: Proporcionar una herramienta para asistir a los profesionales de la salud en la clínica médica en relación contratamientos aún en estudio para combatir el COVID-19 y que sirvan de base para estudios futuros. Métodos: Para el desarrollo de esta revisión sistemática se realizó una investigación en las bases de datos Embase, Pubmed y en clinictrials.gov, con los siguientes criterios de inclusión: selección de ensayos clínicos realizado en adultos, aleatorizados o no, que abordaron la discusión sobre el tratamiento o desarrollo de vacunas para COVID-19. De los artículos encontrados, se seleccionaron 22 estudios y se excluyeron aquellos con un diseño metodológico diferente. Resultados: Estudios Ensayos clínicos que se dividen en doble o triple ciego y presentan riesgo de sesgo. Entre las intervenciones probadas, la hidroxicloroquina y los antivirales son los medicamentos que más prometedor sin control de enfermedades. Sin embargo, los resultados finales aún no están disponibles, ya que los estudios están en curso. Consideraciones finales: Aún no existe evidencia científica de que recomendar el uso de ninguno de los medicamentos probados, si se requiere continuidad y mantenimiento de estudios en curso.

Palabras clave: Covid-19, Terapia, Pandemias.

\section{INTRODUCTION}

In the last decade, viral epidemics have been registered in the world, causing many deaths and infections (CASCELA M, et al., 2020; YUAN J, et al., 2020). In December 2019, the first case of Corona Virus Disease (COVID-19) appeared in the province of Wuhan (China), a disease caused by the new SARS-CoV-2 coronavirus, which, when affecting humans, is capable of causing serious diseases in the tract respiratory and trigger symptoms similar to viral pneumonia, such as fever, cough and dyspnoea (SINGH K, et al., 2020; ZHAI P, et al., 2020).

Due to its high rate of transmissibility, SARS-CoV-2 quickly spread to several countries around the world and on March 11, 2020, COVID-19 was declared pandemic by the World Health Organization (WHO) (SALLARD E, et al., 2020; WHO, 2020). According to Johns Hopkins University, by the time this article was written the number of infected people in the world had already exceeded $10,000,000$ with 504,843 deaths (JOHNS HOPKINS UNIVERSITY, 2020).

SARS-CoV-2, together with SARS-CoV and MERS-CoV, are part of the genus Betacoronavirus, of the Coronaviridae family (CASCELA M, et al., 2020). Between 2002 and 2003, SARS-CoV led to a viral outbreak that reached 12 countries in the world and caused several respiratory manifestations, similar to what happened in the Middle East in 2012 in the MERS-CoV infection (CASCELA M, et al., 2020; JIN Y, et al, 2020).

The mortality rate of the MERS-CoV reached $35 \%$ in the course of its epidemic, a number about $10 \mathrm{x}$ higher than the current pandemic (CASCELA M, et al., 2020; JIN Y, et al, 2020). However, due to its high number of infected people, SARS-CoV-2 has already caused more deaths than the two previous diseases combined (JIN Y, et al, 2020; DE WILDE AH, et al., 2017).

It is known that several studies on the pathophysiology of the disease are still necessary, but some authors suggest that the first step in elucidating the pathogenesis of the infection is the interaction of the virus protein $S$ with the cell receptor ECA-2 (angiotensin-converting enzyme 2) (LENG Z, et al., 2020; TANG X, et al., 2020). After this interaction, the type II transmembrane serine protease enzyme (TMPRSS2) helps the virus to penetrate the cell wall.

The viral RNA is then transcribed and stimulates protein synthesis in the cell's cytoplasm, initiating viral replication that will trigger the release of new viruses (LENG Z, et al., 2020; JIN Y, et al, 2020). Unfortunately, the type II alveolar cells present in the lungs express the ECA-2 receptor and the TMPRSS2 enzyme in large quantities, which could justify the intense involvement of the respiratory system developed in the disease (LENG Z, et al., 2020; JIN Y, et al, 2020). 
The selected clinical trials address the use of several drugs in the management of COVID19. Among the therapies used, the use of chloroquine and hydroxychloroquine was evaluated; antivirals like INF, Lopinavir and Ritonavir; transplantation of mesenchymal cells and glucocorticoids. Although trials have not yet been completed, many expect promising results that would assist in the treatment and control of the current pandemic.

The present study aims to observe the existence of a clinical or therapeutic justification for the use of the various medications tested, the proof of its potential effectiveness and the exposure of the side effects of each treatment.

This review was motivated by the severity of the COVID-19 pandemic worldwide and the lack of definitive studies on the treatment of the disease. The results obtained can contribute to reduce the length of hospitalization of patients, decrease the severity of the disease and, consequently, have a positive effect on mortality rates from SARS-CoV-2. In addition, these researches could indirectly act in preventing a collapse in health systems worldwide, a scenario that is already a reality in several countries affected by the pandemic.

\section{METHODS}

For the development of this systematic review, research was carried out on April 21, 2020 in 2 databases (Embase, Pubmed) and on the website clinicaltrials.gov, following inclusion criteria: selection of clinical trials performed in adults, whether randomized or not, that were in phases I, II, III or IV and addressed the discussion about the treatment or development of vaccines for COVID-19. Studies that presented a methodological design other than a clinical trial, escaped the theme or addressed intervention groups of other age groups other than adults or the elderly (Table 2) were excluded.

In the Embase database, the keywords "COVID-19" and "therapy" were searched using the title, abstract, author keywords, separated by the Boolean operator "AND". The "controlled clinical trial" and "randomized controlled trial" options were selected separated by "OR". Of the 7 articles found, 2 were selected; one of them a protocol and 5 were excluded because they did not fit the theme.

In Pubmed, the same keywords were used with the Boolean operator " AND ", but with the following filters: "clinical trial, phase I", "clinical trial, phase II", "clinical trial, phase IV", " clinical trial, phase III "," controlled clinical trial "," published in the last 5 years "," clinical trial, humans ". 9 results were found, 9 were excluded because they did not fit the theme of the article or the methodological design of those included.

Finally, in the Clinical Trials the keyword used was "COVID-19" associated with "recruiting", "active not recruiting", "completed", "interventional," adult (18-64) "," older adult (65+ ) "," Accepts healthy volunteers "," phase 1 "," phase 2 "," phase 3 "," phase 4 ".

Of the 22 studies found, 2 were excluded for not adapting to the topic. The main objective of this systematic review is to provide a tool that can collaborate effectively in the favorable outcome of patients infected with SARS-CoV-2 (Table 1).

Table 1 - PICO.

\begin{tabular}{|c|c|}
\hline Population & Patients with COVID-19 \\
\hline Intervention & Different therapeutic alternatives used in patients infected with SARS-Cov-2 \\
\hline Comparation & $\begin{array}{r}\text { Patients treated with Hydroxychloroquine, Methylprednisolone or Lopinavir / } \\
\text { Ritonavir x Patients who received vaccination }\end{array}$ \\
\hline Outcome & Improvement in infected patients \\
\hline
\end{tabular}

Source: De Paula LMM, et al., 2020. 
Table 2 - Selection of studies.

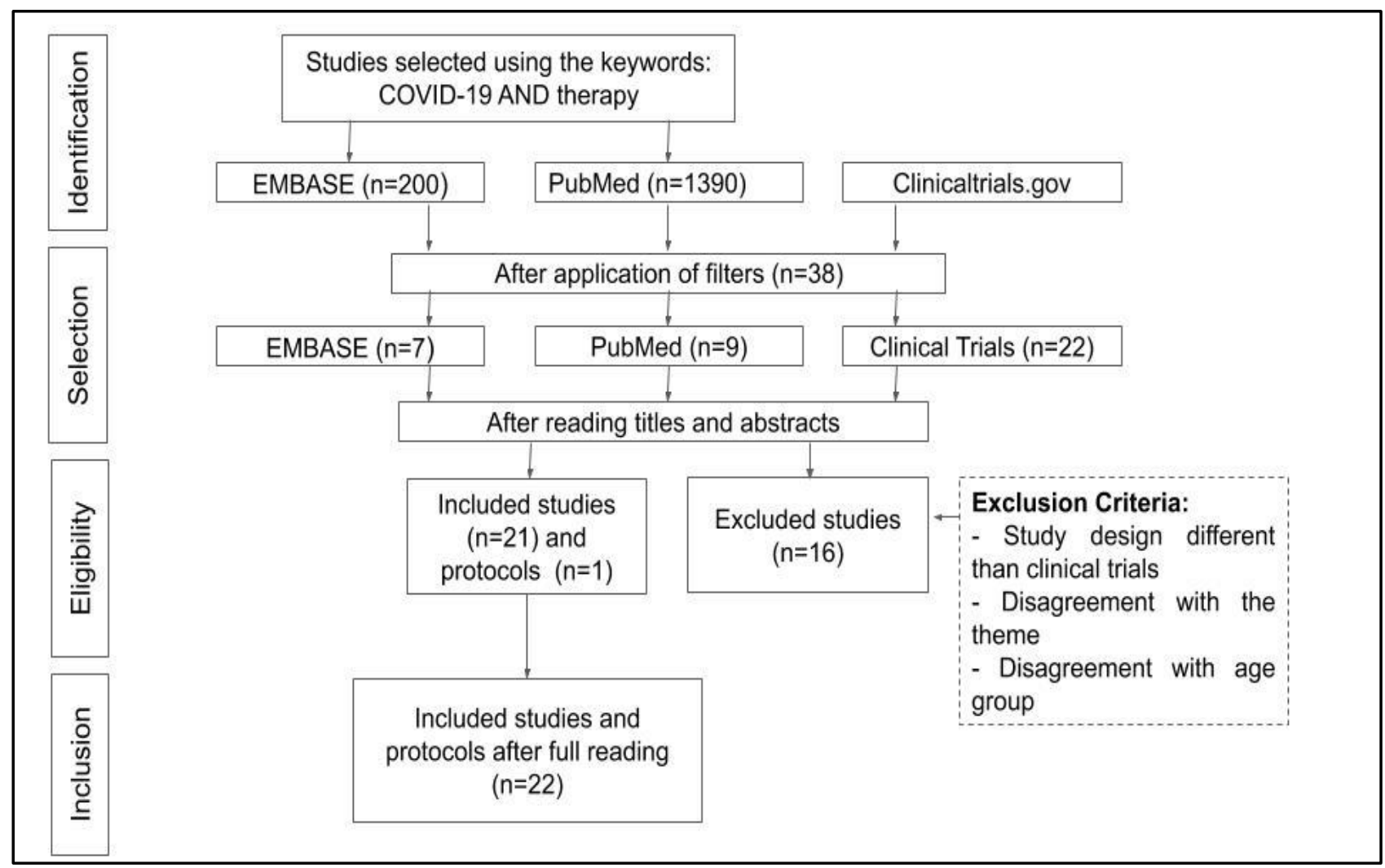

Source: De Paula LMM, et al., 2020. Based in Galvão TF, et al., 2015.

\section{RESULTS}

As a result of this systematic review, 23 articles were found (Table 3) that fit the proposed theme and present a methodological design compatible with a randomized clinical trial. The selected studies are divided into double or triple blind and have criteria to be classified in trials with low risk of bias.

For the development of the studies, patients infected with SARS-Cov-2, health workers and possible close contacts of such patients were recruited. The clinical criteria used by Zhou Y, et al. (2020) to assess the inclusion of these patients were at least one among: Respiratory distress ( $\geq 30$ times / $\mathrm{min}$ ), Oxygen saturation $\leq 93 \%$ at rest, Arterial partial pressure of oxygen (PaO2) / fraction of inspiration O2 (FiO2) $\leq 300 \mathrm{mmHg}(1$ $\mathrm{mmHg}=0.133 \mathrm{kPa}$ ), Respiratory failure requiring mechanical ventilation, septic shock development, critical organ failure requiring intensive care unit care, all of which are commonly found in patients with severe forms of the disease.

The therapeutic regimens proposed for the treatment of confirmed cases of COVID-19 in the clinical trials in question have Hydroxychloroquine as a central pillar, which has been used as a treatment, and sometimes as prevention for high-risk patients. Doses between 200 and $800 \mathrm{mg}$ were tested, in a period ranging from 7 days to 2 months, in order to produce improvement in the patient's clinical parameters and possibly develop a form of prophylaxis in the long term (ZHOU Y, et al.,2020; NCT04328285, 2020; NCT04329923, 2020; NCT04304053, 2020; NCT04331834, 2020; NCT04328961, 2020; NCT04341389, 2020; NCT04341441, 2020; NCT04344379, 2020; NCT04334928, 2020; NCT04353037, 2020; NCT04351724, 2020).

Among the other drugs tested, are: Azithromycin 250mg, Tenofovir Fopratoate Deoproxil 245mg, Emtricitabine 200mg, Lopinavir / Ritonavir 200 / 50mg, Methylpredinisolone 1-2mg / kg / day, Folic Acid and Ascorbic Acid (QIN, et al., 2020; NCT04328285, 2020; NCT04329923, 2020; NCT04304053, 2020; NCT04331834, 2020; NCT04328961, 2020; NCT04341389, 2020; NCT04341441, 2020; NCT04344379, 2020; NCT04334928, 2020; NCT04353037, 2020; NCT04351724, 2020). 
In the context of prophylaxis against future cases, in addition to the use of hydroxychloroquine, some clinical trials propose tests that evaluate the efficacy, safety and immunogenicity of vaccines that have mRNA-1273, BCG (Bacillus Calmette and Guérin) or the adenovirus vector in their composition type 5.

The first one, has viral mRNA encapsulated in lipid nanoparticles and is manufactured from the serum collected from chimpanzees infected with $\mathrm{ChAdOx} 1$, an adenovirus capable of infecting the animal and causing a disease similar to the common cold. BCG, on the other hand, is made with attenuated bacilli of Mycobacterium bovis and is used to prevent severe forms of tuberculosis. Finally, the Ad5-nCoV vaccine is based on recombinant technology and uses type 5 adenovirus as a vector, developing a genetic mutation that causes a defect in viral replication. All tested participants will receive single doses of the vaccines, administered intramuscularly or intradermally, and will have, depending on the trial, monthly, semi-annual and annual followup (NCT04341389, 2020; NCT04324606, 2020; NCT04283461, 2020; NCT04327206, 2020).

Regarding the biases of the reviewed studies (Table 4), 5 types were listed for methodological quality analysis according to the tool provided by Cochrane. The first bias was that of selection; defined by random sequence generation and allocation hiding; if the articles make this explicit, they are considered as low risk of bias, if not, as high risk of bias. If not mentioned, they are considered at risk of uncertain bias.

The performance bias concerns the measures used to blind, both professionals and study participants, thus ensuring the low risk of errors in conduct by both parties that may compromise the quality of the study. The detection bias assesses the blindness of the outcome evaluators, in order to avoid bias in the evaluation of the case and control groups. Friction bias assesses all possible data related to outcomes, their reasons and whether all data included or lost was recorded, avoiding outcomes that contain only data favorable to the study. Finally, the reporting bias assesses the possibility of including only outcomes favorable to the study, thus excluding outcomes that refute or contradict the question to be answered in the randomized clinical trial (DE CARVALHO A, et al., 2013). 
Table 3 - Characteristics of the studies

\begin{tabular}{|c|c|c|c|}
\hline Identification & $\mathrm{N}$ sample and type of participant & Methodological design & Comparison groups and Characterization of the intervention protocol \\
\hline $\begin{array}{l}\text { Zhou Y, et al., } \\
2020 .\end{array}$ & $\begin{array}{l}\mathrm{N}=46 \\
\text { Respiratory distress }(\geq 30 \text { times / min), } \\
\text { Oxygen saturation } \leq 93 \% \text { at rest, Arterial } \\
\text { partial pressure of oxygen }(\mathrm{PaO} 2) / \text { fraction } \\
\text { of inspiration } \mathrm{O} 2(\mathrm{FiO} 2) \leq 300 \mathrm{mmHg}(1 \\
\mathrm{mmHg}=0.133 \mathrm{kPa} \text {, Respiratory failure. }\end{array}$ & $\begin{array}{l}\text { Randomized clinical trial } \\
\text { with } 48 \text { participants lasting } \\
28 \text { days, with } 4 \text { points of } \\
\text { analysis of the patients. }\end{array}$ & $\begin{array}{l}\text { Patients randomized to the intervention group will receive methylprednisolone (intravenous } \\
\text { injection, } 1-2 \mathrm{mg} / \mathrm{kg} / \text { day for } 3 \text { days), control group will not receive glucocorticoid therapy. }\end{array}$ \\
\hline NCT04328285 & $\begin{array}{l}\mathrm{N}=1200 \\
\text { Health workers involved in handling } \\
\text { suspects or confirmed with COVID-19. }\end{array}$ & $\begin{array}{l}\text { Randomized double-blind } \\
\text { placebo-controlled clinical } \\
\text { trial, triple masking, Phase } \\
3\end{array}$ & $\begin{array}{l}\text {-COVIDAXIS 1: Hydroxychloroquine (HCQ) versus placebo; HCQ } 200 \mathrm{mg} \text { : Day } 1: 2 \text { tablets on } \\
\text { the evening Day 2: } 2 \text { tablets on the morning once daily } \\
\text { Placebo of HCQ: Day 1: } 2 \text { tablets on the evening Day 2: } 2 \text { tablets on the morning once daily } \\
\text {-COVIDAXIS 2: Lopinavir/ritonavir (LPV/r) versus placebo. LPV/r } 200 / 50 \mathrm{mg}, 2 \text { tablets twice daily. } \\
\text { Placebo of LPV/r, } 2 \text { tablets twice daily. }\end{array}$ \\
\hline NCT04329923 & $\begin{array}{l}\mathrm{N}=400 \\
\text { Cohort 1: double-blind clinical trial with high } \\
\text { doses of hydroxychloroquine for home } \\
\text { treatment. Cohort 2: randomized study with } \\
\text { different doses of hydroxychloroquine in } \\
\text { hospitalized patients. Cohort } 3 \text { : double- } \\
\text { blind clinical trial testing low doses of } \\
\text { hydroxychloroquine as prevention in } \\
\text { healthcare professionals. }\end{array}$ & $\begin{array}{l}\text { RCT, triple masking, Phase } \\
2\end{array}$ & $\begin{array}{l}\text { Cohort 1: hydroxychloroquine, } 400 \mathrm{mg} \text { twice a day for } 14 \text { days and placebo control } \\
\text { Cohort 2: high doses of hydroxychloroquine, } 600 \mathrm{mg} \text { twice a day in hospitalized patients for } 14 \\
\text { days, compared to low doses of hydroxychloroquine, } 600 \mathrm{mg} \text { once a day, during } 7 \text { days in } \\
\text { hospitalized patients. } \\
\text { Cohort 3: hydroxychloroquine } 600 \mathrm{mg} \text { once a day for } 2 \text { months for health professionals as a } \\
\text { prevention, compared to placebo for } 2 \text { months. }\end{array}$ \\
\hline NCT04304053 & $\begin{array}{l}\mathrm{N}=3040 \\
\text { Researchers want to evaluate the } \\
\text { effectiveness of testing and treating } \\
\text { patients and prophylaxis with } \\
\text { hydroxychloroquine for all contacts. }\end{array}$ & RCT Open Label, Phase 3 & $\begin{array}{l}\text { Control group: no intervention } \\
\text { Index cases will be collected from swab confirmed with PCR on days } 3 \text { and } 7 \text {. Clinical and } \\
\text { demographic information will be collected from all patients. } \\
\text { Experiment: test, treat and prevent SARS-CoV-2 with hydroxychloroquine, } 200 \mathrm{mg} \text { tablets, } 800 \mathrm{mg} \\
\text { on day } 1 \text {, and } 400 \mathrm{mg} \text { (days } 2,3,4,5,6 \text { and } 7 \text { ) also collecting all clinical, demographic and } \\
\text { epidemiological information. Swab PCR will be done on day } 14 \text { of the study. }\end{array}$ \\
\hline NCT04313322 & $\begin{array}{l}\mathrm{N}=5 \\
\text { Patients diagnosed with COVID-19 will } \\
\text { receive } 3 \text { intravenous doses of WJ-MSCs } \\
\text { consisting of } 1 \text { X } 10 \mathrm{e} 6 / \mathrm{kg} \text {. }\end{array}$ & CT Open Label, Phase 1 & $\begin{array}{l}\text { Experiment: WJ-MSCs } \\
\text { WJ-MSCs will be derived from newborn medullary tissue, screened for HIV1 / 2, HBV, CMV, } \\
\text { mycoplasma, and an enriched culture for MSCs. } \\
\text { WJ-MSCs will be administered and a } 25 \mathrm{ml} \text { suspension of saline containing } 0.5 \% \text { human albumin. }\end{array}$ \\
\hline
\end{tabular}

REAS/EJCH | Vol.12(9) | e3963 | DOI: https://doi.org/10.25248/reas.e3963.2020 Página 6 de 14 


\section{Revista Eletrônica Acervo Saúde / Electronic Journal Collection Health ｜ ISSN 2178-2091}

\begin{tabular}{|c|c|c|c|}
\hline NCT04331834 & $\begin{array}{l}\mathrm{N}=440 \\
\text { Health professionals at high risk of SARS- } \\
\text { CoV-2 infection }\end{array}$ & $\begin{array}{l}\text { RCT Quadruple masking, } \\
\text { Phase } 3\end{array}$ & $\begin{array}{l}\text { Experiment: SARS-CoV- } 2 \text { prophylaxis } \\
\text { Participants will receive } 400 \mathrm{mg} \text { once time day of hydroxychloroquine for the first } 4 \text { days, followed } \\
\text { by } 400 \mathrm{mg} \text { per week for the next } 6 \text { months. } \\
\text { Control group will receive placebo for comparison in the same scheme as the intervention group. }\end{array}$ \\
\hline NCT04354428 & $\begin{array}{l}\mathrm{N}=630 \\
\text { Randomized study for the treatment of } \\
\text { severe acute respiratory syndrome in adults } \\
\text { at high risk of infection without the need for } \\
\text { hospitalization. }\end{array}$ & $\begin{array}{l}\text { RCT Double masking, } \\
\text { Phase 2, Pase } 3\end{array}$ & $\begin{array}{l}\text { Placebo: ascorbic acid and folic acid } \\
\text { Ascorbic acid: } 500 \mathrm{mg} \text { twice a/ day }(1 \mathrm{st} \text { day })+250 \mathrm{mg} \text { twice a day for } 9 \text { days }+ \text { folic acid } 800 \mu \mathrm{\mu g} \\
\text { once a day ( } 1 \mathrm{st} \text { day) followed by } 400 \mu \mathrm{g} \text { once a day for another } 4 \text { days } \\
\text { Experiment: } \mathrm{HCQ}+\text { folic acid } \\
\text { HCQ } 400 \mathrm{mg} \text { twice day (1st day) }+200 \mathrm{mg} \text { twice a day for } 9 \text { days }+ \text { placebo } \\
\text { Experiment: } \mathrm{HCQ}+\text { azithromycin } \\
\text { HCQ } 400 \mathrm{mg} \text { twice a dayy (1st day) }+200 \mathrm{mg} \text { twice a day for } 9 \text { days + azithromycin } 500 \mathrm{mg} \text { once } \\
\text { a day (1st day) }+250 \mathrm{mg} \text { once a day for } 4 \text { days. }\end{array}$ \\
\hline NCT04352608 & $\begin{array}{l}\mathrm{N}=744 \\
\text { Total of } 744 \text { participants, } 144 \text { in phase } 1, \\
600 \text { in phase } 2 \text {. Participants will receive } 2 \\
\text { doses of vaccine or placebo on days } 14 \text { and } \\
\text { 28. " }\end{array}$ & $\begin{array}{l}\text { RCT, Quadruple masking, } \\
\text { Phase 1, Phase 2, double } \\
\text { blind }\end{array}$ & $\begin{array}{l}\text { Day } 14 \text { of the trial: } 2 \text { medium doses }(600 \mathrm{SU} / 0,5 \mathrm{ml}), 2 \text { high doses }(1200 \mathrm{SU} / 0.5 \mathrm{ml}) \text {, placebo in } \\
\text { the control group } \\
\text { Day } 28 \text { of the trial: } 2 \text { medium doses ( } 600 \mathrm{SU} / 0.5 \mathrm{ml}), 2 \text { high doses (1200SU / } 0.5 \mathrm{ml}) \text {, placebo in } \\
\text { the control group. }\end{array}$ \\
\hline NCT04341389 & $\begin{array}{l}\mathrm{N}=500 \\
\text { This clinical trial is designed to evaluate the } \\
\text { immunogenicity and safety of Ad5-nCoV } \\
\text { which encodes for a full-length spike (S) } \\
\text { protein of SARS-CoV-2. }\end{array}$ & $\begin{array}{l}\text { RCT, Double masking, } \\
\text { Phase 2, double blinded }\end{array}$ & $\begin{array}{l}\text { Group 1: Ad5-nCoV administered through } 1.0 \mathrm{~mL} \text { intramuscular injection in the deltoid muscle on } \\
\left.\text { Day 0 ( } 1 \times 10^{\wedge} 11 \mathrm{vp}\right) \\
\text { Goup 2: } \mathrm{Ad5}-\mathrm{nCoV} \text { administered through } 1.0 \mathrm{~mL} \text { intramuscular injection in the deltoid muscle on } \\
\text { Day } 0\left(5 \times 10^{\wedge} 10 \mathrm{vp}\right) \\
\text { Placebo group: Placebo administered through } 1.0 \mathrm{~mL} \text { intramuscular injection in the deltoid } \\
\text { muscle on Day } 0\end{array}$ \\
\hline NCT04318015 & 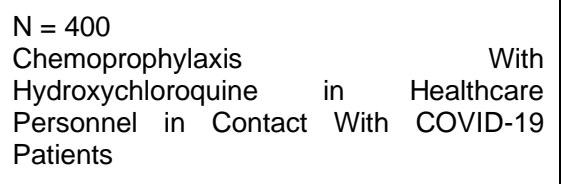 & $\begin{array}{l}\text { RCT, Quadruple masking, } \\
\text { triple blinded }\end{array}$ & $\begin{array}{l}200 \mathrm{mg} \text { of hydroxychloroquine per day vs. placebo } \\
\text { High risk: Hydroxychloroquine } 200 \mathrm{mg} \text { per day for } 60 \text { days. } \\
\text { High risk: Placebo tablet per day for } 60 \text { days } \\
\text { Low risk: Hydroxychloroquine } 200 \mathrm{mg} \text { per day for } 60 \text { days } \\
\text { Low risk: Placebo tablet per day for } 60 \text { days. }\end{array}$ \\
\hline
\end{tabular}

\footnotetext{
REAS/EJCH | Vol.12(9) | e3963 | DOI: https://doi.org/10.25248/reas.e3963.2020 Página 7 de 14
} 


\begin{tabular}{|c|c|c|c|}
\hline NCT04328961 & $\begin{array}{l}\mathrm{N}=2000 \\
\text { The study will include } 2000 \text { participants, } \\
\text { male and female between } 18 \text { and } 80 \text { years } \\
\text { old, including close contacts to patients } \\
\text { tested positive for Covid- } 19 \text {. }\end{array}$ & $\begin{array}{l}\text { RCT, Double masking, } \\
\text { blinded }\end{array}$ & $\begin{array}{l}\text { Placebo: ascorbic acid } \\
\text { Ascorbic acid } 500 \mathrm{mg} 1 \mathrm{x} / \text { day for } 3 \text { days }+250 \mathrm{mg} 1 \mathrm{x} / \text { day for } 11 \text { days. } \\
\text { Intervention: hydroxychloroquine } \\
\text { Hydroxychloroquine } 400 \mathrm{mg} 1 \mathrm{x} / \text { day for } 3 \text { days }+200 \mathrm{mg} 1 \mathrm{x} / \text { day for } 11 \text { days }\end{array}$ \\
\hline NCT04341441 & $\begin{array}{l}\text { The study will have } 3000 \text { health } \\
\text { professionals as participants }\end{array}$ & $\begin{array}{l}\text { RCT, Triple masking, } \\
\text { blinded }\end{array}$ & $\begin{array}{l}\text {-Hydroxychloroquine treatment group: They will receive a } 200 \mathrm{mg} \text { oral dose daily following day } 1 \\
\text { dose of } 400 \mathrm{mg} \text { orally once. } \\
\text {-Once weekly randomized treatment group: They will receive the proposed dose of } \\
\text { hydroxychloroquine for prophylaxis of malaria is } 6.5 \mathrm{mg} / \mathrm{kg} \text { per dose orally weekly on the same } \\
\text { day (each week). } \\
\text {-Placebo: } 2 \text { pills a day } \\
\text {-Non-randomized group of health professionals and rescuers in chronic use of oral } \\
\text { hydroxychloroquine for their autoimmune diseases. }\end{array}$ \\
\hline NCT04313127 & $\begin{array}{l}108 \text { participants, aged between } 18 \text { and } 60 \\
\text { years, adults, previously healthy }\end{array}$ & $\begin{array}{l}\text { Non randomized CT, Open } \\
\text { label, Phase } 1\end{array}$ & $\begin{array}{l}\text { Group 01: Low dose. Subjects received a dose of } 5 \mathrm{E} 10 \mathrm{vp} \text { Ad5-nCoV } \\
\text { Group 02: Average dose. Subjects received a dose of } 1 \mathrm{E} 11 \mathrm{vp} \text { Ad5-nCoV } \\
\text { Group 03: High doses. Subjects received a dose of } 1.5 \mathrm{E} 11 \mathrm{vp} \text { Ad5-nCoV }\end{array}$ \\
\hline NCT04344379 & $\begin{array}{l}\text { The study aims to select } 900 \text { health } \\
\text { professionals, who tested negative for } \\
\text { SARS-CoV-2 }\end{array}$ & $\begin{array}{l}\text { RCT double masking, } \\
\text { Phase } 3\end{array}$ & $\begin{array}{l}\text { Active comparator: hydroxychloroquine, } 200 \mathrm{mg} \text { BID per day } \\
\text { Placebo comparator: hydroxychloroquine placebo, } 200 \mathrm{mg} \text { BID per day } \\
\text { Active comparator: azithromycin, } 250 \mathrm{mg} \text { per day }\end{array}$ \\
\hline NCT04327206 & $\begin{array}{l}\text { The study consists of } 4170 \text { health } \\
\text { professionals }\end{array}$ & RCT Open label, phase 3 & $\begin{array}{l}\text { Group 01: You will receive a dose of BCG vaccine } \\
\text { Group 02: Participants will not receive the BCG vaccine }\end{array}$ \\
\hline NCT04324606 & $\begin{array}{l}1112 \text { volunteers aged between } 18 \text { and } 55 \\
\text { years were selected }\end{array}$ & $\begin{array}{l}\text { RCT, Single masking, } \\
\text { Phase 1, Phase } 2\end{array}$ & 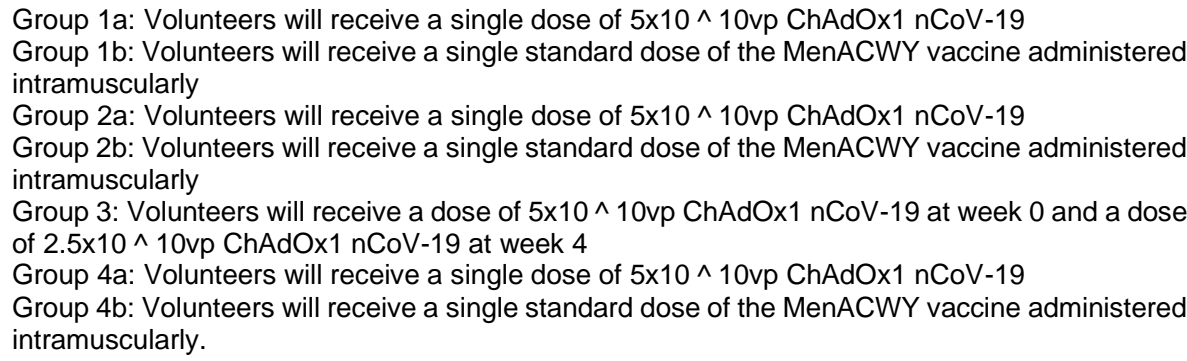 \\
\hline
\end{tabular}

REAS/EJCH | Vol.12(9) | e3963 | DOI: https://doi.org/10.25248/reas.e3963.2020 Página 8 de 14 


\begin{tabular}{|c|c|c|c|}
\hline NCT04334928 & $\begin{array}{l}4000 \text { health professionals aged between } 18 \\
\text { and } 70 \text { years were selected }\end{array}$ & $\begin{array}{l}\text { RCT, Double masking, } \\
\text { Phase } 3\end{array}$ & $\begin{array}{l}\text { Group 01: Tenofovir Disoproxil Fumarate } 245 \mathrm{mg} \text { / Emtricitabine } 200 \mathrm{mg}+\text { Hydroxychloroquine } \\
\text { placebo } 200 \mathrm{mg} \\
\text { Group 02: Hydroxychloroquine } 200 \mathrm{mg}+\text { Tenofovir Disoproxil fumarate placebo } 245 \mathrm{mg} \text { / } \\
\text { Emtricitabine } 200 \mathrm{mg} \\
\text { Group 03: Tenofovir Disoproxil Fumarate } 245 \mathrm{mg} \text { / Emtricitabine } 200 \mathrm{mg}+\text { Hydroxychloroquine } \\
200 \mathrm{mg} \\
\text { Group 04: Tenofovir disoproxil fumarate placebo } 245 \mathrm{mg} \mathrm{/} \mathrm{emtricitabine} 200 \mathrm{mg}+ \\
\text { Hydroxychloroquine } 200 \mathrm{mg} \text { placebo. }\end{array}$ \\
\hline NCT04353037 & $\begin{array}{l}\text { The study will have } 850 \text { participants aged } \\
\text { between } 50 \text { and } 75 \text { years }\end{array}$ & $\begin{array}{l}\text { RCT, Double masking, } \\
\text { Phase } 2\end{array}$ & $\begin{array}{l}\text { Group A: Patients tested for COVID- } 19 \text { who meet the symptomatology and age requirements for } \\
\text { eligibility. Damn: HCQ } \\
\text { Group B: Health workers infected by COVID-19 (confirmed by accepted tests) in } 2 \text { months. } \\
\text { Damn: HCQ. }\end{array}$ \\
\hline NCT04283461 & $\begin{array}{l}\text { The study aims to select } 45 \text { people aged } \\
\text { leen } 18 \text { and } 55 \text { years }\end{array}$ & $\begin{array}{l}\text { Non randomized clinical } \\
\text { trial, Open label, Phase } 1\end{array}$ & $\begin{array}{l}\text { Group 01: } 25 \mathrm{mcg} \text { of mRNA-1273 administered by intramuscular injection of } 0.5 \mathrm{~mL} \text { into the } \\
\text { deltoid muscle on days } 1 \text { and } 29 . \mathrm{n}=15 \text { ( } 4 \text { sentinel, } 11 \text { not sentinel) } \\
\text { Group 02: } 100 \mathrm{mcg} \text { of mRNA-1273 administered by intramuscular injection of } 0.5 \mathrm{~mL} \text { into the } \\
\text { deltoid muscle on days } 1 \text { and } 29 . \mathrm{n}=15 \text { ( } 4 \text { sentinel, } 11 \text { not sentinel) } \\
\text { Group 03: } 250 \text { mcg of mRNA-1273 administered by intramuscular injection of } 0.5 \mathrm{~mL} \text { into the } \\
\text { deltoid muscle on Days } 1 \text { and } 29 . \mathrm{n}=15 \text { ( } 4 \text { sentinel, } 11 \text { not sentinel). }\end{array}$ \\
\hline NCT04336410 & $\begin{array}{l}\text { The study will have } 40 \text { participants aged } \\
\text { between } 18 \text { and } 50 \text { years }\end{array}$ & $\begin{array}{l}\text { Non randomized clinical } \\
\text { trial, Open label, Phase } 1\end{array}$ & $\begin{array}{l}\text { Group 01: Participants will receive an ID injection of } 1.0 \text { milligram (mg) of INO-4800, followed by } \\
\text { EP using the CELLECTRA® } 2000 \text { device per dosing visit } \\
\text { Group 02: Participants will receive two injections of } 1.0 \mathrm{mg} \text { ID (total } 2.0 \mathrm{mg} \text { per dose visit) of INO- } \\
4800 \text {, followed by PE using the CELLECTRA® } 2000 \text { device per dose visit }\end{array}$ \\
\hline NCT04351724 & $\begin{array}{l}\text { The study will have } 500 \text { participants aged } \\
\text { between } 18 \text { and } 99 \text { years }\end{array}$ & $\begin{array}{l}\text { RCT Open Label, Phase 2, } \\
\text { Phase } 3\end{array}$ & $\begin{array}{l}\text { Group 01: Hydroxychloroquine } 200 \mathrm{mg} \text { 2-0-2 on day } 1 \text {, followed by } 200 \mathrm{mg} \text { 1-0-1 or Chloroquine } \\
250 \mathrm{mg} \text { 2-0-2, as available } \\
\text { Group 02: patients will be treated with a "' standard of care "'", which prevents treatment with } \\
\text { lopinavir / ritonavir or hydroxychloroquine } \\
\text { Group 03: blockade of the renin-angiotensin system (SARS) by ingesting candesartan starting } \\
\text { with 4mg once daily and titrated for patients with normotension> } 120 / 80 \mathrm{mmHG} \text { are eligible } \\
\text { Group 04: RAS non-blocking antihypertensive agents, titrated to normotension } \\
\text { Group 05: Clazakizumab. Patients with respiratory deterioration qualify for this treatment arm }\end{array}$ \\
\hline $\begin{array}{l}\text { CAO B, et al., } \\
2020\end{array}$ & - & $\begin{array}{l}\text { Protocol for the } \\
\text { administration } \quad \text { of } \\
\text { lopinavir/ritonavir to such } \\
\text { patients and their clinical } \\
\text { monitoring. }\end{array}$ & $\begin{array}{l}\text { Lopinavir / ritonavir } 200 \mathrm{mg} / 50 \mathrm{mg} \text { - two tablets every } 12 \mathrm{~h} \text { for } 14 \text { days or when becoming } \\
\text { asymptomatic after } 7 \text { days it is used. And for patients who are unable to take medication orally, } \\
\text { via nasogastric sounds, } 400 \mathrm{mg} \text { of lopinavir / } 100 \mathrm{mg} \text { of ritonavir } 5 \mathrm{ml} \text { of suspension every } 12 \\
\text { hours for } 14 \text { days or when becoming asymptomatic after } 7 \text { days is used. }\end{array}$ \\
\hline
\end{tabular}

Source: De Paula LMM, et al., 2020. Based in ClinicalTrials, 2020; Zhou Y, et al., 2020; Cao B, et al., 2020. 
Table 4 - Methodological quality

\begin{tabular}{|c|c|c|c|c|c|c|}
\hline Identification & Selection bias & $\begin{array}{l}\text { Performance } \\
\text { bias }\end{array}$ & Detection bias & Friction bias & Reporting bias & Other biases \\
\hline $\begin{array}{c}\text { Zhou Y, et al., } \\
2020 .\end{array}$ & Low risk of bias & Low risk of bias & Low risk of bias & $\begin{array}{l}\text { Study still being } \\
\text { conducted }\end{array}$ & $\begin{array}{l}\text { Study still being } \\
\text { conducted }\end{array}$ & $\begin{array}{l}\text { Study still being } \\
\text { conducted }\end{array}$ \\
\hline NCT04328285 & Low risk of bias & Low risk of bias & Low risk of bias & $\begin{array}{l}\text { Study still being } \\
\text { conducted }\end{array}$ & $\begin{array}{l}\text { Study still being } \\
\text { conducted }\end{array}$ & $\begin{array}{l}\text { Study still being } \\
\text { conducted }\end{array}$ \\
\hline NCT04329923 & Low risk of bias & Low risk of bias & Low risk of bias & $\begin{array}{l}\text { Study still being } \\
\text { conducted }\end{array}$ & $\begin{array}{l}\text { Study still being } \\
\text { conducted }\end{array}$ & $\begin{array}{l}\text { Study still being } \\
\text { conducted }\end{array}$ \\
\hline NCT04304053 & Low risk of bias & Low risk of bias & Low risk of bias & $\begin{array}{l}\text { Study still being } \\
\text { conducted }\end{array}$ & $\begin{array}{l}\text { Study still being } \\
\text { conducted }\end{array}$ & $\begin{array}{l}\text { Study still being } \\
\text { conducted }\end{array}$ \\
\hline NCT04313322 & Low risk of bias & Low risk of bias & Low risk of bias & $\begin{array}{l}\text { Study still being } \\
\text { conducted }\end{array}$ & $\begin{array}{l}\text { Study still being } \\
\text { conducted }\end{array}$ & $\begin{array}{l}\text { Study still being } \\
\text { conducted }\end{array}$ \\
\hline NCT04331834 & Low risk of bias & Low risk of bias & Low risk of bias & $\begin{array}{l}\text { Study still being } \\
\text { conducted }\end{array}$ & $\begin{array}{l}\text { Study still being } \\
\text { conducted }\end{array}$ & $\begin{array}{l}\text { Study still being } \\
\text { conducted }\end{array}$ \\
\hline NCT04354428 & Low risk of bias & Low risk of bias & Low risk of bias & $\begin{array}{l}\text { Study still being } \\
\text { conducted }\end{array}$ & $\begin{array}{l}\text { Study still being } \\
\text { conducted }\end{array}$ & $\begin{array}{l}\text { Study still being } \\
\text { conducted }\end{array}$ \\
\hline NCT04352608 & Low risk of bias & Low risk of bias & Low risk of bias & $\begin{array}{l}\text { Study still being } \\
\text { conducted }\end{array}$ & $\begin{array}{l}\text { Study still being } \\
\text { conducted }\end{array}$ & $\begin{array}{l}\text { Study still being } \\
\text { conducted }\end{array}$ \\
\hline NCT04341389 & Low risk of bias & Low risk of bias & Low risk of bias & $\begin{array}{l}\text { Study still being } \\
\text { conducted }\end{array}$ & $\begin{array}{l}\text { Study still being } \\
\text { conducted }\end{array}$ & $\begin{array}{l}\text { Study still being } \\
\text { conducted }\end{array}$ \\
\hline NCT04318015 & Low risk of bias & Low risk of bias & Low risk of bias & $\begin{array}{l}\text { Study still being } \\
\text { conducted }\end{array}$ & $\begin{array}{l}\text { Study still being } \\
\text { conducted }\end{array}$ & $\begin{array}{l}\text { Study still being } \\
\text { conducted }\end{array}$ \\
\hline NCT04328961 & Low risk of bias & Low risk of bias & Low risk of bias & $\begin{array}{l}\text { Study still being } \\
\text { conducted }\end{array}$ & $\begin{array}{l}\text { Study still being } \\
\text { conducted }\end{array}$ & $\begin{array}{l}\text { Study still being } \\
\text { conducted }\end{array}$ \\
\hline NCT04341441 & Low risk of bias & Low risk of bias & Low risk of bias & $\begin{array}{l}\text { Study still being } \\
\text { conducted }\end{array}$ & $\begin{array}{l}\text { Study still being } \\
\text { conducted }\end{array}$ & $\begin{array}{l}\text { Study still being } \\
\text { conducted }\end{array}$ \\
\hline NCT04313127 & Low risk of bias & Low risk of bias & Low risk of bias & $\begin{array}{l}\text { Study still being } \\
\text { conducted }\end{array}$ & $\begin{array}{l}\text { Study still being } \\
\text { conducted }\end{array}$ & $\begin{array}{l}\text { Study still being } \\
\text { conducted }\end{array}$ \\
\hline NCT04344379 & Low risk of bias & Low risk of bias & Low risk of bias & $\begin{array}{l}\text { Study still being } \\
\text { conducted }\end{array}$ & $\begin{array}{l}\text { Study still being } \\
\text { conducted }\end{array}$ & $\begin{array}{l}\text { Study still being } \\
\text { conducted }\end{array}$ \\
\hline NCT04327206 & Low risk of bias & Low risk of bias & Low risk of bias & $\begin{array}{l}\text { Study still being } \\
\text { conducted }\end{array}$ & $\begin{array}{l}\text { Study still being } \\
\text { conducted }\end{array}$ & $\begin{array}{l}\text { Study still being } \\
\text { conducted }\end{array}$ \\
\hline NCT04324606 & Low risk of bias & Low risk of bias & Low risk of bias & $\begin{array}{l}\text { Study still being } \\
\text { conducted }\end{array}$ & $\begin{array}{l}\text { Study still being } \\
\text { conducted }\end{array}$ & $\begin{array}{l}\text { Study still being } \\
\text { conducted }\end{array}$ \\
\hline NCT04334928 & Low risk of bias & Low risk of bias & Low risk of bias & $\begin{array}{l}\text { Study still being } \\
\text { conducted }\end{array}$ & $\begin{array}{l}\text { Study still being } \\
\text { conducted }\end{array}$ & $\begin{array}{l}\text { Study still being } \\
\text { conducted }\end{array}$ \\
\hline NCT04353037 & Low risk of bias & Low risk of bias & Low risk of bias & $\begin{array}{l}\text { Study still being } \\
\text { conducted }\end{array}$ & $\begin{array}{l}\text { Study still being } \\
\text { conducted }\end{array}$ & $\begin{array}{l}\text { Study still being } \\
\text { conducted }\end{array}$ \\
\hline NCT04283461 & Low risk of bias & Low risk of bias & Low risk of bias & $\begin{array}{l}\text { Study still being } \\
\text { conducted }\end{array}$ & $\begin{array}{l}\text { Study still being } \\
\text { conducted }\end{array}$ & $\begin{array}{l}\text { Study still being } \\
\text { conducted }\end{array}$ \\
\hline NCT04336410 & Low risk of bias & Low risk of bias & Low risk of bias & $\begin{array}{l}\text { Study still being } \\
\text { conducted }\end{array}$ & $\begin{array}{l}\text { Study still being } \\
\text { conducted }\end{array}$ & $\begin{array}{l}\text { Study still being } \\
\text { conducted }\end{array}$ \\
\hline NCT04351724 & Low risk of bias & Low risk of bias & Low risk of bias & $\begin{array}{l}\text { Study still being } \\
\text { conducted }\end{array}$ & $\begin{array}{l}\text { Study still being } \\
\text { conducted }\end{array}$ & $\begin{array}{l}\text { Study still being } \\
\text { conducted }\end{array}$ \\
\hline $\begin{array}{c}\text { CAO B, et al., } \\
2020\end{array}$ & Low risk of bias & Low risk of bias & Low risk of bias & $\begin{array}{l}\text { Study still being } \\
\text { conducted }\end{array}$ & $\begin{array}{l}\text { Study still being } \\
\text { conducted }\end{array}$ & $\begin{array}{l}\text { Study still being } \\
\text { conducted }\end{array}$ \\
\hline
\end{tabular}

Source: De Paula LMM, et al., 2020. Based in ClinicalTrials, 2020; ZHOU Y, et al., 2020; CAO B, et al., 2020. 


\section{DISCUSSION}

The new SARS-CoV-2 coronavirus, which appeared in China on December 8, 2019, quickly spread around the world, characterizing a pandemic according to the WHO in early March 2020. As a result, the search intensified for a treatment for COVID-19 that is effective, safe and effective, since it is characterized not only by a disease of mild to moderate severity, but that can also generate Severe Acute Respiratory Syndrome (SARS) leading to a rate low lethality, but which, compared to certain risk groups, represents a significant amount. Thus, in addition to clinical support and protocol treatment, several researchers around the world are testing the use of drugs of the most diverse classes in order to reduce the morbidity and mortality of the disease. The main drugs found in the research of this systematic review are: antivirals, Chloroquine, Hydroxychloroquine and glucocorticoids, which will be discussed below (YOUNG HU, et al., 2020; ZHOU Y, et al., 2020).

Hydroxychloroquine has been widely used in the world for about seventy years, being widely used for the treatment of malaria and chronic inflammatory diseases, such as systemic lupus erythematosus (SLE) and rheumatoid arthritis (RA). However, for use in SARS-CoV-2 the result remains uncertain. In vitro studies have shown that the drug can block viral infection by increasing endosomal $\mathrm{pH}$ and interfering with the glycosylation of the SARS-CoV cell receptor, as well as in the proteolytic process. The study authors also mention the possibility of an immunomodulatory effect of the drug and point out that due to the low cost and safety of the drug and dosage, it would become a viable alternative (CORTEGIANI A, et al., 2020; SANDERS J, et al., 2020).

A French study published on March 17, 2020 evaluated the efficacy of Hydroxychloroquine as monotherapy or associated with Azithromycin in patients with COVID-19. Forty six patients diagnosed with the disease participated in the study and were followed up for 14 days, with daily nasopharyngeal swab collection and viral load assessment using the RT-PCR (Real-time reverse transcription-polymerase chain) technique. Of these, 26 participants received $200 \mathrm{mg}$ of Hydroxychloroquine orally, in three daily doses in the first ten days; 6 also received Azithromycin orally and 6 patients did not complete the test. Patients who used the medication had a higher rate of viral clearance from the sixth day $(70 \%$ vs $12.5 \%, p=0.001)$ and those who received it in association with Azithromycin had $100 \%$ clearance on the sixth day. The results are very satisfactory, but the study has several biases, such as a very small sample, in addition to being non-blind and non-randomized, and also cannot associate the primary outcome with clinical improvement or decreased transmission. Therefore, caution is still needed when using this medication for both SARS and MERS (Middle East Respiratory Syndrome) - and also a member of the coronavirus family; since the medication has adverse effects that can be serious and also increase the morbidity and mortality of patients treated with it (GAUTRET P, et al., 2020; SANDERS J, et al., 2020).

The glucocorticoid Methylprednisolone was also used with the intention of decreasing the host's response in the lungs, which could contribute to the development of the Acute respiratory distress syndrome (ARDS). However, the threshold between benefits and adverse effects is very thin, as it can decrease viral clearance and increase the risk of secondary infection. Methylprednisolone was evaluated at a dose of $1-2 \mathrm{mg} / \mathrm{kg} / \mathrm{day}$, intravenously, for 3 days, in critically ill patients, although it has been widely used in previous SARS epidemics, especially in 2003 , has controversial literature regarding its effectiveness. Some studies have shown that its mechanism of action of corticosteroids would involve the reduction of inflammatory interleukins such as Interleukin 8 (IL-8), and by reducing the inflammatory reaction in the lungs there is a reduction in the chance of developing respiratory failure, however others have shown to be a risk factor for mortality, with the presence of complications such as hyperglycemia, psychosis and avascular necrosis (ZHOU Y, et al., 2020; TSANG OTY, et al., 2003; SANDERS J, et al., 2020).

Antiretrovirals, of which Lopinavir and Ritonavir stand out, were tested in vitro and showed inhibition of the new coronavirus type 3-chymotrypsin protease. A clinical trial was carried out with 199 patients, 99 received the medication and it was observed that these patients did not have a better outcome than the control group, that is, there was no significant clinical improvement and the mortality rate after 28 days was similar. The authors themselves report that there were several biases in the study, such as the absence of blinding and the collection of less frequent samples (CAO B, et al., 2020). 
Among all the studies conducted, the one with the greatest range of therapeutic options is carried out by the Medical University of Vienna, in which in addition to the drugs previously mentioned, there are also: Rivaroxabana, Clazakizumab, Candesartan, thromboprophylaxis and other antihypertensive drugs whose mechanism of action do not involve blocking the Renin-Angiotensin-Aldosterone pathway (NCT04351724, 2020). The therapeutic effect of monoclonal antibodies seems to be involved in blocking IL-6 (differently from corticosteroids, which in the inflammatory cascade seem to influence IL-8 more), which is involved in the dysregulation of the immune and inflammatory response to infection.

The mechanism that would make antihypertensive drugs involved in the renin-angiotensin system (RAS) is directly related to the pathophysiology of the disease in which a certain interaction of the $S$ protein virus with the host Angiotensin-converting enzyme II (ACE II) receptor would occur. Thus, of all the medications present in the researched studies up to the time this review was written, there was no confirmed evidence of a specific drug for the treatment of COVID-19 according to the guidelines of the World Health Organization through the following document "Clinical management of severe acute respiratory infection when novel coronavirus (2019nCoV) infection is suspected "(CORTEGIANI A, et al., 2020; SANDERS J, et al., 2020).

In addition to treatment, research has been instituted that also involves the use of prophylaxis by health professionals working to combat COVID-19, as it is known that how the transmission of the disease remains not fully described - the possibilities of the equipment itself being reported individual protection may not be enough to protect them, which generated about $4 \%$ of infection. Thus, a study at the Center Hospitalier Universitaire de Saint Etienne in France is being conducted using the following prophylactic options: 1) Hydroxychloroquine, 2) Hydroxychloroquine placebo, 3) Lopinavir and Ritonavir and 4) Antiretroviral placebo.

On the other hand, contact prophylaxis is being addressed in a study by Fundacio Lluita Contra la SIDA in which contacts of infected patients will receive Hydroxychloroquine $800 \mathrm{mg}$ on the first day and $400 \mathrm{mg}$ on subsequent days, which may vary from 4 to 7 days. The research is based on the fact that previous studies on influenza indicated that antiviral drugs can reduce infectivity, since it reduces the viral load in the pulmonary secretion of patients (NCT04328285, 2020; NCT04304053, 2020).

Although, as previously mentioned, several information about the new disease is inconclusive, such as pathophysiology and form of transmission, the genetic material of the virus was quickly released by the Chinese, which allowed research on vaccines to be carried out promptly. And so, only efforts to seek drugs for prophylaxis also continue to grow, during the development of this review, a study was conducted by Sinovac Biotech Co in which the safety and immunogenicity of a possible inactivated SARS CoV-2 virus vaccine for prophylaxis COVID-19 is being evaluated (NCT04352608, 2020).

Meanwhile, the Institute of Biotechnology, Academy of Military Medical Sciences, PLA of China is also evaluating the safety and immunogenicity of its possible Ad5-nCoV recombinant vaccine, which encodes a SARS-CoV-2 virus protein and acts on viral replication. In addition, the laboratory Inovio Pharmaceuticals conducts a study in which it also assesses the safety, tolerance and immunogenicity of a vaccine named by the same as INO-4800 (NCT04336410, 2020; ZHOU Y, et al., 2020).

\section{Study limitations}

Although it is a systematic review with works on such a current topic, some limitations of this work must be taken into account. In the researched literature, the severity of the disease was not classified in the same way, with the same parameters, in the different studies found. Regarding treatment, the choice of drugs and the criteria for using them had relevant differences. As this is a current topic, it is possible to identify the asymmetry between the studies, either by the amount of drugs used, by the period in which they were used, by the samples used and as previously mentioned by the criteria used to receive or not receive such drugs. However, in the course of the studies themselves, it is expected that they will reach the necessary and desired conclusions all over the world regarding this new disease that has so quickly become a worldwide public health emergency (YONG HU, et al., 2020, CORTEGIANI A, et al., 2020). 


\section{FINAL CONSIDERATIONS}

The SARS-CoV-2 pandemic has become a serious public health problem worldwide. In view of the international emergency situation established by COVID-19, until now there is no scientific evidence to recommend the use of any of the drugs tested in ongoing trials. For this reason, it is necessary to maintain investments in research and clinical trials. This review serves as a basis for future research and seeks to collaborate effectively in the favorable outcome of patients infected with SARS-CoV-2.

\section{REFERENCES}

1. BHATNAGAR T, et al. Lopinavir/ritonavir combination therapy amongst symptomatic coronavirus disease 2019 patients in India: Protocol for restricted public health emergency use. Indian Journal of Medical Research, 2020; 151(2):184.

2. CASCELLA M, et al. Features, Evaluation and Treatment Coronavirus (COVID-19). StatPearls Publishing, 2020; $1: 122$.

3. $\mathrm{CAO} B$, et al. A Trial of Lopinavir-Ritonavir in Adults Hospitalized with Severe Covid-19. The New England journal of medicine, 2020; 382:1787-1799.

4. CORTEGIANI A, et al. A systematic review on the efficacy and safety of chloroquine for the treatment of COVID-19. Journal Of Critical Care, 2020; 57: 279-283.

5. DE CARVALHO A, et al. Avaliação do risco de viés de ensaios clínicos randomizados pela ferramenta da colaboração Cochrane. Diagn Tratamento, 2013; 18(1):38-44.

6. DE WILDE AH, et al. Alisporivir inhibits MERS-and SARS-coronavirus replication in cell culture, but not SARScoronavirus infection in a mouse model. Virus research, 2017; 228:7-13.

7. GALVÃO TFP, et al. Principais itens para relatar Revisões sistemáticas e Meta-análises: A recomendação PRISMA. Epidemiologia e Serviços de Saúde, 2015; 24(2): 335-342.

8. GAUTRET P, et al. Hydroxychloroquine and azithromycin as a treatment of COVID-19: results of an open-label nonrandomized clinical trial. International Journal of Antimicrobial Agents, 2020; 106949.

9. JOHNS HOPKINS UNIVERSITY. 2020. In: Coronavirus COVID-19 Global Cases Johns Hopkins University. United States: Coronavirus Global cases. Available on: https://coronavirus.jhu.edu/map.html. Acessed on: 29 jun. 2020.

10. JIN Y, et al. Virology, epidemiology, pathogenesis, and control of COVID-19. Viruses, 2020; 12(4):72.

11. LENG Z, et al. Transplantation of ACE2-mesenchymal stem cells improves the outcome of patients with COVID-19 pneumonia. Aging and disease, 2020; 11(2):216-228.

12. NCT04283461. NATIONAL INSTITUTE OF ALLERGY AND INFECTIOUS DISEASES. Safety and Immunogenicity Study of 2019-nCoV Vaccine (mRNA-1273) for Prophylaxis of SARS-CoV-2 Infection (COVID-19). Available on: https://clinicaltrials.gov/ct2/show/NCT04283461. Access on: 21 apr. 2020.

13. NCT04304053. FUNDACIO LLUITA CONTRA LA SIDA. Treatment of COVID-19 Cases and Chemoprophylaxis of Contacts as Prevention. Available on: https://clinicaltrials.gov/ct2/show/NCT04304053. Access on: 21 apr. 2020.

14. NCT04313127. CANSINO BIOLOGICS INC. Phase I Clinical Trial of a COVID-19 Vaccine in 18-60 Healthy Adults. Available on: https://clinicaltrials.gov/ct2/show/NCT04313127. Access on: 21 apr. 2020.

15. NCT04313322. STEM CELLS ARABIA. Treatment of COVID-19 Patients Using Wharton's Jelly-Mesenchymal Stem Cells. Available on: https://clinicaltrials.gov/ct2/show/NCT04313322. Access on: 21 apr. 2020.

16. NCT04318015. NATIONAL INSTITUTE OF RESPIRATORY DISEASES. Hydroxychloroquine Chemoprophylaxis in Healthcare Personnel in Contact With COVID-19 Patients (PHYDRA Trial). Available on: https://www.clinicaltrials.gov/ct2/show/NCT04318015. Access on: 21 apr. 2020.

17. NCT04324606. UNIVERSITY OF OXFORD. A Study of a Candidate COVID-19 Vaccine. Available on: https://clinicaltrials.gov/ct2/show/NCT04324606. Access on: 21 apr. 2020.

18. NCT04327206. MURDOCH CHILDRENS RESEARCH INSTITUTE. BCG Vaccination to Protect Healthcare Workers Against COVID-19. Available on: https://clinicaltrials.gov/ct2/show/NCT04327206. Access on: 21 apr. 2020.

19. NCT04328285. CENTRE HOSPITALIER UNIVERSITAIRE DE SAINT ETIENNE. Chemoprophylaxis of SARS-CoV-2 Infection (COVID-19) in Exposed Healthcare Workers. Available on: https://clinicaltrials.gov/ct2/show/NCT04328285. Access on: 21 apr. 2020.

20. NCT04328961. UNIVERSITY OF WASHINGTON. Hydroxychloroquine for COVID-19 Post-exposure Prophylaxis. Available on: https://clinicaltrials.gov/ct2/show/NCT04328961. Access on: 21 apr. 2020.

21. NCT04329923. AMARAVADI, R. The PATCH Trial (Prevention And Treatment of COVID-19 With Hydroxychloroquine). Available on: https://clinicaltrials.gov/ct2/show/NCT04329923. Access on: 21 apr. 2020.

22. NCT04331834. BARCELONA INSTITUTE FOR GLOBAL HEALTH. Pre-Exposure Prophylaxis With Hydroxychloroquine for High-Risk Healthcare Workers During the COVID-19 Pandemic. Available on: https://clinicaltrials.gov/ct2/show/NCT04331834. Access on: 21 apr. 2020.

23. NCT04334928. PLAN NACIONAL SOBRE EL SIDA. Randomized Clinical Trial for the Prevention of SARS-CoV-2 Infection (COVID-19) in Healthcare Personnel. Available on: https://clinicaltrials.gov/ct2/show/NCT04334928. Access on: 21 apr. 2020. 
24. NCT04336410. INOVIO PHARMACEUTICALS. Safety, Tolerability and Immunogenicity of INO-4800 for COVID-19 in Healthy Volunteers. Available on: https://clinicaltrials.gov/ct2/show/NCT04336410. Access on: 21 apr. 2020.

25. NCT04341389. INSTITUTE OF BIOTECHNOLOGY, ACADEMY OF MILITARY MEDICAL SCIENCES, PLA OF CHINA. A Phase II Clinical Trial to Evaluate the Recombinant Vaccine for COVID-19 (Adenovirus Vector). Available on: https://clinicaltrials.gov/ct2/show/NCT04341389. Access on: 21 apr. 2020.

26. NCT04341441. HENRY FORD HEALTH SYSTEM. Will Hydroxychloroquine Impede or Prevent COVID-19. Available on: https://clinicaltrials.gov/ct2/show/NCT04341441. Access on: 21 apr. 2020.

27. NCT04344379. ASSISTANCE PUBLIQUE, HÔPITAUX DE PARIS. Prevention of ARS-CoV-2 in Hospital Workers s Exposed to the Virus. Available on: https://clinicaltrials.gov/ct2/show/NCT04344379. Access on: 21 apr. 2020.

28. NCT04351724. MEDICAL UNIVERSITY OF VIENNA. Austrian CoronaVirus Adaptive Clinical Trial (COVID-19). Available on: https://clinicaltrials.gov/ct2/show/NCT04351724. Access on: 21 apr. 2020.

29. NCT04352608. SINOVAC RESEARCH AND DEVELOPMENT CO., LTD. Safety and Immunogenicity Study of Inactivated Vaccine for Prophylaxis of SARS CoV-2 Infection (COVID-19). Available on: https://clinicaltrials.gov/ct2/show/NCT04352608. Access on: 21 apr. 2020.

30. NCT04353037. UNITEDHEALTH GROUP. PATCH 2\&3:Prevention \& Treatment of COVID-19 (Severe Acute Respiratory Syndrome Coronavirus2) Wit Hydroxychloroquine. Available on: https://clinicaltrials.gov/ct2/show/NCT04353037. Access on: 21 apr. 2020.

31. NCT04354428. UNIVERSITY OF WASHINGTON. Treatment for COVID-19 in High-Risk Adult Outpatients. Available on: https://clinicaltrials.gov/ct2/show/NCT04354428. Access on: 21 apr. 2020.

32. SALLARD E, et al. Type 1 interferons as a potential treatment against COVID-19. Antiviral Research, 2020; 178:104791.

33. SANDERS JM, et al. Pharmacologic treatments for coronavirus disease 2019 (COVID-19): a review. Journal of the American Medical Association, 2019; 323(18):824-1836.

34. SINGH AK, et al. Chloroquine and hydroxychloroquine in the treatment of COVID-19 with or without diabetes: a systematic search and a narrative review with a special reference to India and other developing countries. Diabetes \& Metabolic Syndrome: Clinical Research \& Reviews, 2020; 14(3):241-246.

35. TANG X, et al. On the origin and continuing evolution of SARS-CoV-2. National Science Review, 2020.

36. TSANG OTY, et al. Coronavirus-positive nasopharyngeal aspirate as predictor for severe acute respiratory syndrome mortality. Emerging infectious diseases, 2003; 9(11):1381.

37. WORLD HEALTH ORGANIZATION. 2020. In: WHO United States: Director-General's opening remarks at the media briefing on COVID-19. Available on: https://www.who.int/dg/speeches/detail/who-director-general-s-opening-remarksat-the-media-briefing-on-covid-19---11-march-2020. Acessed on: 20 apr. 2020.

38. YONG HU, et al. Prevalence and severity of corona virus disease 2019 (COVID-19): a systematic review and metaanalysis: A systematic review and meta-analysis. Journal Of Clinical Virology, 2020; 1(1):104371-104374.

39. YUAN J, et al. The correlation between viral clearance and biochemical outcomes of 94 COVID-19 infected discharged patients. Inflammation Research, 2020; 69:599-606.

40. ZHAI P, et al. The epidemiology, diagnosis and treatment of COVID-19. International Journal of Antimicrobial Agents, 2020; 55(5):105955.

41. ZHOU Y, et al. Effectiveness of glucocorticoid therapy in patients with severe novel coronavirus pneumonia. Chinese Medical Journal, 2020; 133(9):1080-1086. 